Running head: IDENTITY, THREAT AND ATTITUDES TO COUNTER-TERRORISM

\title{
Pride and Prejudice: Exploring How Identity Processes Shape Public Attitudes towards Australian Counter-terrorism Measures
}

\begin{abstract}
Counter-terrorism measures are often described as pre-emptive, punitive, and afford authorities exclusive and expanded powers. Yet they continue to attract public support (Huddy, Feldman, Taber, \& Lahav, 2005; Welch, 2016). Why is this the case? A consistent finding in traditional crime control research shows a link between perceived threat from racial or ethnic minority groups and their perceived involvement in crime. This perceived relationship results in public support for punitive crime control measures for such groups. Similar connections can be made between terrorism and Muslims. It is thus possible that perceiving Muslims to be threatening may help explain enhanced public support towards harsh counter-terrorism measures. This study draws on survey data of a national sample Australian residents $(\mathrm{N}=1,199)$ to test this hypothesis.

Findings show the importance of both identity processes and perceptions of Muslims as threatening in shaping support for punitive counter-terrorism strategies. Results also demonstrate how social identity can moderate the effect of perceived threat on support for such strategies. Theoretical and policy implications of this study are outlined.
\end{abstract}

Keywords: social identity; punitive attitudes; terrorism; Muslims; identity threat 


\section{IDENTITY, THREAT AND ATTITUDES TO COUNTER-TERRORISM MEASURES}

\section{Introduction}

The terrorism threat has catalysed preventative and reactive legislative responses globally, which receive widespread public and political support (Huddy, et al., 2005). Paralleling these measures are pervasive discourses associating terrorism with Muslims and Islam (Cherney \& Murphy, 2016). The normalisation of this rhetoric within social and political narratives can be problematic for the livelihoods of those feeling targeted by counter-terrorism responses, and for perpetuating reactive responses to national security threats. Thus, it is important to canvas how the public views legislative responses to terrorism, and whether attitudes are influenced by prejudiced beliefs towards Muslims.

Research highlights how some minority groups are perceived as more threatening than others (e.g., Stephan et al., 2000). Perceptions of threat stem from evaluating others as less favourable than oneself (Oliveira \& Murphy, 2014). These attitudes derive from Social Identity Theory (SIT), which conceptualises how individuals assign themselves to specific groups based on whether they perceive they are similar or different to others (Tajfel \& Turner, 1986). In recent years, public and political sentiment has centered on the scrutiny of Muslims as a 'suspect group' (Breen-Smyth, 2014; Cherney \& Murphy, 2016); thereby highlighting how Muslims can be perceived as a threat and an outgroup in contemporary society.

Relatedly, scholarly interest has focused on the relationship between threat perceptions and punitive attitudes towards certain groups. Unnever and Cullen (2010a, 2010b) argue that negative evaluations of minorities are likely to shape punitive attitudes toward crime control measures. They hypothesise that individuals may believe the crime control policies they support will target these minority groups. It is therefore possible that perceiving Muslims as a threatening 
IDENTITY, THREAT AND ATTITUDES TO COUNTER-TERRORISM MEASURES

outgroup may elicit more punitive attitudes to counter-terrorism measures that often target Muslims (Doosje, et al., 2009).

This study explores the impact of identity threat on public attitudes towards counterterrorism measures. In addition to understanding the effect of identity threats, this paper canvases the relationship between social identity processes and attitudes supportive of punitive counterterrorism initiatives. The following section overviews existing literature on punitive attitudes, drawing from the traditional crime control literature and studies that specifically examine terrorism. From here the theoretical framework underpinning this study is outlined, followed by the hypotheses and methodology. The findings and wider contributions of the research are then discussed.

\section{Public Punitiveness and Counter-Terrorism}

Following 9/11, counter-terrorism laws have been broadened and continue to receive public support (Welch, 2016). Policies established in Australia and countries including the United States (US) and the United Kingdom (UK) are generally punitive because they afford authorities exclusive powers to surveil, detain and interrogate individuals without reasonable suspicion or proof of criminal intent (Lynch, McGarrity, \& Williams, 2015). The increasingly punitive nature of these measures since $9 / 11$ is largely a reflection of public support for harsh counter-terrorism policies (Huddy et al., 2005).

Scholars argue that counter-terrorism policies disproportionately scrutinise Muslims (Doosje, Zimmermann, Küpper, Zick, \& Meertens, 2009). The use of these measures perpetuate the suspect communities phenomenon, which Hillyard argues is the use of extraordinary executive powers towards a particular group of people deemed a suspect community (Hillyard, 1993). Hillyard's (1993) framework was used to examine Irish terror suspects in the 1970s, with 
IDENTITY, THREAT AND ATTITUDES TO COUNTER-TERRORISM MEASURES

this perspective relevant for Muslim communities in a post-9/11 era (see also Pantazis \& Pemberton, 2009; Cherney \& Murphy, 2016). Within Australia, the majority of terrorist plots and attacks have been committed by perpetrators identifying as Muslim (Zammit, 2017). Thus, terrorism laws are applied more frequently to Muslim defendants. These trends may justify why some people perceive Muslims as a greater threat and in turn support counter-terrorism policies that target terrorism suspects. However, as these defendants represent a small minority of the overall Australian Muslim population, more ingrained prejudiced views generalising all Muslims as a threat may actually drive support for these punitive policies. In this sense, perceptions of threat may derive not from a realistic threat that Muslims pose a safety, political or well-being risk, but a symbolic threat rooted in intergroup differences in values and beliefs (Stephan, DiazLoving, \& Duran, 2000).

The nature of punishment is often shaped by perceptions that certain groups are threatening (Chiricos, Welch, \& Gertz, 2004). Punitive sentiment and harsh crime control policies correlate with heightened perceptions of threat towards groups deemed to be the criminal other (Unnever \& Cullen, 2010a). While common to the traditional crime control context (see e.g., Chiricos et al., 2004), a similar outcome is observable when examining the effects of counter-terrorism laws and policing approaches. Muslims report experiencing Islamophobia, prejudice, and hate crimes against their group (Akbarzadeh, 2016), highlighting the pervasive stigma they face as a criminal (or terrorist) other (Murphy, Madon, \& Cherney, 2018). It is therefore possible that perceiving Muslims as threatening may shape public attitudes supportive of harsh counter-terrorism policies and laws. The present study tests this notion, drawing on a social psychological framework of identity and public reactions to perceived threat.

\section{Social Identity Theory: A Framework for Understanding Punitive Attitudes}




\section{IDENTITY, THREAT AND ATTITUDES TO COUNTER-TERRORISM MEASURES}

Social Identity Theory (SIT) proposes that individuals align themselves to social groups, compare themselves to others, and then assign themselves to an ingroup or outgroup (Tajfel \& Turner, 1986). Those who identify with an ingroup feel a sense of belonging to that group. Ingroup membership is premised on shared values and beliefs, and a shared identity with other ingroup members (Oliveira \& Murphy, 2014). In contrast, outgroups include individuals who do not belong to one's ingroup. Members of outgroups are perceived by others in a much less favourable light, and are considered to hold values and beliefs contrasting those of the ingroup (Oliveira \& Murphy, 2014). Hence, intergroup bias stems from the perception that some individuals belong to one's group, while others do not (Tajfel \& Turner, 1986).

Previous research highlights that strong ingroup identification is a key antecedent of perceived threat from outgroup members (Stephan, et al., 2000). The tenets of SIT suggest individuals who identify strongly with their ingroup are more inclined to protect the strength of their identities (Tajfel \& Turner, 1986), by for example, acting to reduce a threat against their group from an outgroup (Velasco González, Verkuyten, Weesie, \& Poppe, 2008). Unnever and Cullen (2010a) propose that people are more likely to support punitive crime control policies if they perceive that these policies target individuals who are threatening to ingroup members.

SIT is an important framework for understanding how prejudice towards an outgroup can impact on an ingroup's attitudinal or behavioural intentions (Huddy et al., 2005). Indeed, analysing punitive sentiment arguably requires acknowledging its symbiotic connection with the oppression of racial and ethnic groups (Frost, 2006). Disproportionate trends in arrest, conviction, and imprisonment rates of certain minority groups, particularly Black, Hispanic and Indigenous populations are demonstrative of the unbalanced nature of the criminal justice system (Chiricos et al., 2004). Moreover, the perceived association between minority groups and 
IDENTITY, THREAT AND ATTITUDES TO COUNTER-TERRORISM MEASURES

criminality is well-established in the literature (Unnever \& Cullen, 2010a, 2010b). Research consistently demonstrates a racial disparity in punishment preferences, with individuals more likely to support harsh crime control policies that they believe target minority (out)groups (Welch, 2016).

Evidence suggests that highly nationalistic individuals of a non-minority background express outgroup members as more threatening (Stephan et al., 2000), and thus adopt more punitive attitudes toward minorities. For example, Doosje et al. (2009) utilised a nationally representative survey sample of non-Muslim residents living in nine European countries to examine whether prejudice was associated with outgroup discrimination and approval of antiimmigration measures. The authors suggest when members of the national group perceive Muslims to support terrorism (i.e., as a threat), they are more likely to discriminate against Muslims and endorse restrictive immigration policies limiting Muslim migration. Doosje et al. (2009) also examined how perceptions of terrorism threat (operationalised as the belief that the participant would be a victim of terrorism) can affect punitive attitudes towards anti-immigration policies. Findings showed when people perceive a terrorism threat, their attitudes towards Muslims become increasingly prejudiced and discriminatory (Doosje et al., 2009).

This research points to the relationship between pride and prejudice. Specifically, scholars argue that pride in national identity can manifest as patriotism or nationalism. While the former is described as an individual's sense of attachment to their country, and is associated with lower levels of intolerance or prejudice, the latter refers to feelings of superiority and dominance, and is often linked to stronger prejudicial attitudes toward outgroup members (Li \& Brewer, 2004). Li and Brewer (2004), for example, studied Americans' views of Muslims shortly after the 9/11 attacks. Using an experimental methodology, Li and Brewer (2004) found that when 
IDENTITY, THREAT AND ATTITUDES TO COUNTER-TERRORISM MEASURES

respondents' nationalistic identities were salient, respondents were more likely to hold prejudiced views of Muslims.

\section{The Impact of Minority Threat on Punitive Attitudes}

The relationship between outgroup intolerance and support for punitive punishments is supported empirically, particularly in the traditional crime control context (see e.g., Chiricos et al., 2004; Kornhauser, 2013; Unnever \& Cullen, 2010a, 2010b). For example, Chiricos et al. (2004) examined whether the racial typification of crime was associated with support for punitive crime control measures. Using a national random survey sample of 885 American adults, findings showed that participants were more likely to be punitive when they perceived that black citizens committed more crime. This finding held even when controlling for fear of crime, concerns about crime, and perceptions around the proportion of violent crime. The authors concluded by suggesting that crime control preferences were driven by racialised typifications of criminality. In Australia, Kornhauser (2013) conducted a quantitative analysis of 3,902 Australian participants, finding a significant and positive relationship between racial animus and support for two crime control strategies: harsher sentences and the death penalty. ${ }^{1}$ Unnever and colleagues (2010a, 2010b) also find a consistent relationship between negative sentiment towards minority groups and support for harsh punishment preferences across a range of countries, including Europe, Canada, and the US.

Underpinning the notion that threat and intolerance shapes punitive attitudes is the racial animus model (Unnever \& Cullen, 2010b). Cullen and colleagues (2010a, 2010b) suggest that punitive attitudes are more salient when individuals negative evaluate minority groups. The racial animus model draws from two prominent theoretical frameworks: the minority threat

\footnotetext{
1 The death penalty was abolished in Australia in 1985.
} 
IDENTITY, THREAT AND ATTITUDES TO COUNTER-TERRORISM MEASURES

thesis and the racial typification of crime thesis. The minority threat thesis links racial prejudice with discrimination and increased group-based social control towards minority groups (Blumer, 1958). In a similar vein, the racial typification of crime thesis centers around denoting the outgroup as an other and associating them with criminality (Chiricos et al., 2004). These attitudes subsequently enhance attitudes favourable of punitive crime control policies serving to elevate the ingroup's status (Weitzer \& Tuch, 2005).

\section{Punitive Attitudes and the Muslim Experience}

While the link between racial animus and punitive attitudes to crime control policies is well-documented in the crime control literature, scant research exists in the counter-terrorism context (but see Piazza, 2015; Welch, 2016). Negative portrayals that target individuals identifying as Muslim, Arab or of Middle Eastern descent pervade social and political discourses (Velasco González et al., 2008). These patterns of outgroup prejudice and othering are similar to observable stereotypes towards Black and Hispanic citizens with respect to crime (Unnever \& Cullen, 2012).

It is important to note that while religion and race are distinct, racism and religious discrimination are often treated analogously (Khan \& Ecklund, 2012). Despite the ethnic heterogeneity of Muslims, they are often deemed a homogenous group (Saeed, 2007). Moreover, for Muslims, indicators of their identities are often prominent. Among females, wearing a headscarf is a form of religious expression for Muslims (Verkuyten \& Yildiz, 2010). For males, markers of identity include forms of dress and beards in some instances (Hopkins, 2004). As such, their religious markers mean they represent a visible minority in much the same way as African-Americans or Hispanics. Further, given these observable indicators, it is conceivable that 


\section{IDENTITY, THREAT AND ATTITUDES TO COUNTER-TERRORISM MEASURES}

the link between outgroup threat and support for punitive terrorism measures may also be observed when examining perceived threat from Muslims.

The most recent research examining public perceptions of punitive counter-terrorism policies found a strong relationship between racialised stereotypes, outgroup threat, and support for counter-terrorism policies. Welch (2016) drew on American survey data from 425 adults to examine whether linking individuals of Middle Eastern descent with terrorism predicted support for punitive counter-terrorism policies. Findings revealed that punitive attitudes were stronger among those who negatively stereotyped Middle Eastern individuals. These results mirror those found in the traditional crime context (see e.g., Chiricos et al., 2004).

In another study, Sides and Gross (2013) explored whether support for the War on Terror was linked to public perceptions of Muslims. Using two sets of election attitudes data gathered in the $\mathrm{US}^{2}$, the authors found that negative portrayals of Muslims as violent and untrustworthy was associated with heightened support for the War on Terror (Sides \& Gross, 2013). The authors suggested counter-extremism strategies that reinforce these stereotypes, in conjunction with continued violence in Middle Eastern countries, prolongs stereotyping among majority nonMuslim groups towards minority Muslim groups (Sides \& Gross, 2013).

Other studies also find that perceiving Muslims as a terrorist threat can increase public support for measures such as those involving torture (Piazza, 2015), banning headscarves (Van der Noll, 2010), and restricting civil liberties (Nisbet, Ostman, \& Shanahan, 2008). Recent research reveals that people harbour more punitive attitudes when they perceive Muslims to be threatening. For example, Piazza (2015) drew on a US sample to compare the public's views of Muslim and non-Muslim hypothetical terror suspects to discern differences in punitive sentiment

\footnotetext{
2 The two datasets used in the analyses were the American National Election Study (ANES) and the Cooperative Congressional Election Studies (CCES)
} 
IDENTITY, THREAT AND ATTITUDES TO COUNTER-TERRORISM MEASURES

towards the use of interrogation and detention techniques. Using an experimental vignette design that manipulated the religious affiliation of terrorism suspects, Piazza (2015) found suspected terrorists' religious identities, namely Muslim identities, were positively associated with the public's support for punitive interrogation and detention measures. Moreover, the hypothetical suspects' affiliations with a specific terrorist organisation were also related to more punitive attitudes. Participants were more punitive towards hypothetical suspects linked to groups inspired by distortions of Islam than groups not inspired by these doctrines (Piazza, 2015). Findings of Piazza's study demonstrate a link between how individuals typify "terrorist suspects" and their tolerance of harsh punishments for Muslims. Aligning with research linking racial and ethnic prejudice with punitive sentiment towards traditional crime control measures, these aforementioned studies highlight the applicability of animus toward Muslims in shaping punitive attitudes towards counter-terrorism measures.

\section{The Current Study}

The above literature review highlights a consistent link between perceptions of minority threat and attitudes supportive of punitive crime control measures. While this relationship has been widely tested in the traditional crime context, the evidence base around how minority threat shapes punitive attitudes towards counter-terrorism measures is less developed. Moreover, the social identity processes associated with the relationship between perceptions of threat and punitive attitudes have not been tested in the counter-terrorism context.

The present study applies SIT to examine how perceptions of threat towards Muslims impacts support for punitive counter-terrorism measures. Specifically, this study examines how identity threat (i.e., perceptions that Muslims are a threat to one's way of life) and national identity at the superordinate level predicts attitudes supportive of punitive counter-terrorism 


\section{IDENTITY, THREAT AND ATTITUDES TO COUNTER-TERRORISM MEASURES}

measures. Also of interest is the moderating role of national identity in shaping such attitudes when people perceive Muslims as threatening. Scholars have not yet examined the interaction between perceived threat and national identity variables to explain support for punitive counterterrorism measures. The current study does so in the Australian counter-terrorism context. It is predicted that those who perceive Muslims as more threatening and those who more strongly identify as Australian may be more likely to support punitive counter-terrorism measures. Three primary hypotheses guide these predictions:

H1: A heightened sense of threat from Muslims will be associated with stronger support for punitive counter-terrorism measures.

H2: A strong national identity (i.e., ingroup identity) will be associated with attitudes more supportive of punitive counter-terrorism measures.

H3: National identity will interact with perceptions that Muslims are threatening to shape attitudes in support of punitive counter-terrorism measures. Specifically, those with a stronger national identity will be more supportive of punitive counter-terrorism measures when they perceive Muslims as more threatening.

\section{Methods}

\section{Participants and Procedure}

The data used for this study was drawn from an online survey fielded via Facebook among a sample of Australians in January 2018. 1,423 people across all Australian states and territories accessed the survey link and completed the survey. The survey benchmarked public attitudes towards counter-terrorism measures and forms of punishment in the traditional crime context. The survey also measured participants' sense of national identity, their tolerance to 
IDENTITY, THREAT AND ATTITUDES TO COUNTER-TERRORISM MEASURES

diversity, and their perceptions of threat from minority groups (Williamson, Murphy, \& Sargeant, 2018).

After examining survey non-response and conducting a missing data analysis, data for 224 surveys were discarded, leaving a final sample size of 1,119 participants. The sample included $57.2 \%$ females, and the average age of participants was 36.2 years old $(\mathrm{SD}=14.22)$. Australian-born participants comprised the majority of the sample (84.1\%). Almost all participants reported being Australian citizens (96.5\%). Over one-quarter of participants (28.2\%) had completed a trade/technical certificate or diploma, followed by those who had completed high school and those with a Bachelor's degree, who represented $21.5 \%$ and $23.2 \%$ of the sample respectively. The majority of the sample reported working full-time (37.9\%), followed by those who were students (18.3\%) and those working part-time (17.6\%). Almost two-thirds of the sample reported having no religion $(61.0 \%$; see Table 1$)$.

Given the nature of the sampling procedure, the survey sample is not nationally representative of the Australian population. Specifically, there is a slight over-representation of females (by $7.1 \%)$, and a greater proportion of participants aged between 15 and 24 years $(28.5 \%$ more than Australian Bureau of Statistics census figures). Participants aged 65 or over comprised $4.6 \%$ of the survey, which is $11.2 \%$ less than the Australian population. The differences in these demographic breakdowns can be attributable to the characteristics of Facebook users, as there is a higher proportion of young Facebook users and female users (Aslam, 2018). There is also an over-representation of participants from Queensland (14.3\% more than census statistics). This outcome may be due to the fact that recruitment occurred on a Facebook page originating in Queensland.

\section{Measurement Construction}


IDENTITY, THREAT AND ATTITUDES TO COUNTER-TERRORISM MEASURES

Three scales were constructed to represent the key variables of interest: support for punitive counter-terrorism measures; national identity and perceptions that Muslims are threatening (see Table 1 for the wording of items used in each scale). All scale items were measured on a five-point Likert scale (e.g., $1=$ strongly disagree to $5=$ strongly agree). The construct validity of the three key scales was assessed using Principal Axis factor analysis using oblimin rotation. Results revealed three distinct factors (see Table 1).

Dependent variable. The dependent variable in this study is support for punitive counterterrorism measures. It was constructed using nine items that measure the extent to which participants approved of policies that seek to prevent or respond to terrorism. Each item asked participants to rate on a 5-point Likert scale (i.e., $1=$ strongly disapprove to $5=$ strongly approve) their level of approval with each policy, such as the use of stressful interrogation techniques; intercepting telecommunications; or revoking citizenship when convicted of a terrorism offence. A higher score on the mean constructed scale indicated stronger approval of more punitive measures $(\mathrm{M}=3.05 ; \mathrm{SD}=0.98$, Cronbach alpha $=0.91)$.

Independent variables. Two scales were constructed to represent the two key independent variables: national identity and perceptions that Muslims are threatening. The items used within each scale were measured on a five-point Likert scale ranging from strongly disagree (1) to strongly agree (5).

National identity. The 3-item national identity scale was adapted from Murphy (2013) to measure participants' strength of national identity (i.e., Australian identity). Survey participants were asked how much pride they felt being Australian and whether they identified strongly as an Australian. A higher score on the national identity scale indicated a stronger sense of Australian identity $(\mathrm{M}=3.81 ; \mathrm{SD}=0.93$, Cronbach alpha $=0.85)$. 


\section{IDENTITY, THREAT AND ATTITUDES TO COUNTER-TERRORISM MEASURES}

Perceptions that Muslims are threatening. This 7-item scale was adapted from the work of Velasco González et al. (2008). This scale measures the extent to which participants feel Muslims are a threat to Australian values and their way of life, and was measured on a 1 (strongly disagree) to 5 (strongly agree) scale. Those scoring higher on this scale perceive Muslims as more threatening $(\mathrm{M}=2.22 ; \mathrm{SD}=1.16$; Cronbach alpha=0.97).

[Table 1 here]

Control variables. Previous research often highlights demographic differences in support for punitive policies (see e.g., Welch, 2016). Thus, the following demographic variables were included: age $(\mathrm{M}=36.2 ; \mathrm{SD}=14.2)$; gender $(0=$ female; $1=$ male $)$; country of birth $(0=$ overseas born; 1=Australian born); educational attainment (ranging from 1=did not complete high school to $6=$ postgraduate qualifications $)$; religion; and employment status $(0=$ not employed; $1=$ employed). ${ }^{3}$

In addition to the demographic variables, two further control measures were added: political orientation and fear of terrorism. Previous research highlights the importance of controlling for fear of crime/terrorism (Welch, 2016) as potential predictors of support for punitive measures. Thus, a fear of terrorism measure is included in this paper. Similarly, prior studies demonstrate that punitive attitudes toward punishing offenders are stronger when participants hold more right-wing, conservative, or nationalistic beliefs (Chiricos et al., 2004; Welch, 2016). Participants were asked to rank how 'left' or 'right' leaning they were on a scale from 1 to 10 (where 1 is more left leaning and 10 is more right leaning) $)^{4}$. Table 2 provides the

${ }^{3}$ Employment (1) represented participants who identified that they were working part-time; working fulltime; studying and working; self-employed; or a casual worker. Those who were not employed (0) identified that they were a student; had home duties; were unemployed and seeking work; retired; or on a pension.

${ }^{4}$ In Australia, left leaning is more socialist e.g., the Australian Labor Party (ALP); the Greens, while right leaning would be more conservative e.g., the Liberal National Party (LNP); One Nation. 


\section{IDENTITY, THREAT AND ATTITUDES TO COUNTER-TERRORISM MEASURES}

descriptive statistics for the control variables and the three scales, as well as the associated bivariate relationships between measures.

[Table 2 here]

\section{Results}

Ordinary Least Squares regression analysis was conducted to determine whether public support for punitive counter-terrorism measures was shaped by national identity and perceptions that Muslims pose a threat to Australian values (see Table 3). Variables were entered in blocks to determine the variance each block contributed to the final model. In Block 1, demographic variables and two control variables of interest (fear of terrorism and political orientation) were added. In Block 2, the measure of national identity and the variable representing perceptions that Muslims are threatening were added. In Block 3, a two-way interaction between national identity and perceptions that Muslims are threatening was entered into the model. The scales were meancentered before being entered into the model.

\section{[Table 3 here]}

The demographic variables added in Block 1 accounted for $41 \%$ of the variance in attitudes approving of punitive counter-terrorism measures. All control variables entered were statistically significant. Political orientation $(\beta=0.38, \mathrm{p}<0.001)$ and fear of terrorism $(\beta=0.37$, $\mathrm{p}<0.001)$ were most strongly and positively associated with attitudes supportive of punitive counter-terrorism measures. Those who were more right leaning (i.e., conservative) and who were more fearful of terrorism were more supportive of punitive counter-terrorism measures. Gender $(\beta=0.12, \mathrm{p}<0.001)$, employment status $(\beta=0.10, \mathrm{p}<0.001)$, and age $(\beta=0.11, \mathrm{p}<0.001)$ were also positively associated with heightened punitive attitudes towards counter-terrorism measures. Specifically, women, those who were employed and older participants were more 
IDENTITY, THREAT AND ATTITUDES TO COUNTER-TERRORISM MEASURES

supportive of punitive measures. Country of birth $(\beta=-0.06, p<0.05)$ and educational attainment $(\beta=-0.11, p<0.001)$ were negatively associated with punitive attitudes. Participants born in Australia and those who reported being more highly educated were less supportive of punitive counter-terrorism measures.

In Block 2, $\left(\mathrm{R}^{2}\right.$ change $\left.=0.10\right)$, the national identity and perceptions that Muslims are threatening variables were entered. The inclusion of all variables in this block accounted for $51 \%$ of the variance in participants' attitudes in support of punitive counter-terrorism measures. Those who identified more strongly as Australian $(\beta=0.13, \mathrm{p}<0.001)$ and those who viewed Muslims as more threatening $(\beta=0.39, \mathrm{p}<0.001)$ were more supportive of punitive measures. Except for gender $(\beta=0.15, \mathrm{p}<0.001)$, political orientation $(\beta=0.18, \mathrm{p}<0.001)$, and fear of terrorism $(\beta=0.23, \mathrm{p}<0.001)$, the strength of the association between other control variables and support for punitive counter-terrorism measures was reduced or eliminated on entry of the two key independent variables.

Finally, in Block 3 a two-way national identity x perceptions that Muslims are threatening interaction term was introduced $\left(\mathrm{R}^{2}\right.$ change $\left.=0.01\right)$. This interaction effect was negative and significant $(\beta=-0.07, \mathrm{p}<0.001$; see Figure 1). Simple effects tests were computed at -1 (low) and +1 (high) standard deviation of national identity to examine the nature of the interaction effect in more depth. While participants who identified more strongly with Australia, and who perceived Muslims as more threatening were most supportive of punitive counterterrorism measures overall, findings from the simple effects analyses show that perceiving Muslims as a threat to public safety affected low national identifiers more strongly $(\beta=0.47$, $\mathrm{p}<0.001)$ when compared to those who identified more strongly as Australian $(\beta=0.33$, $\mathrm{p}<0.001)$. In other words, low national identifiers became more supportive of punitive counter- 
IDENTITY, THREAT AND ATTITUDES TO COUNTER-TERRORISM MEASURES

terrorism measures only when they perceived Muslims to be a greater threat. High Australian identifiers were already much more likely to support punitive counter-terrorism measures.

[Figure 1 here]

\section{Discussion and Implications}

This study utilised a social identity framework to examine the association between social identity and perceptions of Muslim threat on punitive attitudes towards counter-terrorism measures. Findings highlight that when controlling for control variables, perceptions of Muslims as threatening matter most for explaining attitudes supportive of punitive counter-terrorism measures. Those who perceived Muslims to be a greater threat were more supportive of punitive counter-terrorism measures (Hypothesis 1 supported). Another key focus of this study was to examine the association between ingroup identity and approval of punitive counter-terrorism measures. Indeed, participants whose national identity as an Australian was stronger were more supportive of punitive counter-terrorism measures than those whose national identity was weaker (Hypothesis 2 supported).

The relationship between national identity and punitive attitudes towards counterterrorism measures was tested further by exploring the moderating influence of perceiving Muslims as a threat. The interaction effect between national identity and Muslim threat was statistically significant. Respondents who identified more strongly with Australia and who perceived Muslims as threatening were most likely to support punitive counter-terrorism measures (support for Hypothesis 3). However, the interaction effect revealed that perceiving Muslims as threatening increased weak national identifiers' punitive attitudes to the same level as strong national identifiers. When the perceived threat posed by Muslims was low, weak Australian identifiers were less likely to support punitive counter-terrorism measures. 


\section{IDENTITY, THREAT AND ATTITUDES TO COUNTER-TERRORISM MEASURES}

While not a major focus of the current study, the findings also revealed positive associations between support for punitive counter-terrorism measures and fear about terrorism and political orientation. Specifically, those who were more fearful of terrorism and those who were more right-leaning were more likely to support punitive counter-terrorism measures.

\section{Study limitations}

Before discussing the implications of the findings, some limitations of the present study must be considered. Firstly, the data used is cross-sectional; thus causal relationships implied between the key variables cannot be determined. Secondly, this data is not nationally representative, which limits the generalisability of the findings to all Australians. As data was collected through a social media platform, the sample size is determined by those who click the link and agree to participate. Specifically, the Facebook recruitment method attracted younger participants than would generally be captured in survey research. Most traditionally administered Australian surveys are conducted via telephone or mail tend to oversample older participants (for an example in the Australian context, see Murphy, 2013). Thus, while not representative by age, findings from this study spotlight attitudes from a younger sample. Older people are often found to hold more punitive attitudes than younger people (Adriaenssen \& Aertsen, 2015). Thus, had older respondents been more represented in the present study, findings may have revealed more support for punitive counter-terrorism measures.

Thirdly, the construction of the national identity variable does not account for the numerous ways in which individuals construct and nurture their identities. For example, national identity was used as a proxy for the strength of ingroup identification. However, it is possible that Muslims who are Australian citizens also identify very strongly as Australian and see themselves as a member of the ingroup. As such, the measure may not be ideal to assess ingroup 
IDENTITY, THREAT AND ATTITUDES TO COUNTER-TERRORISM MEASURES

identification. Future research may wish to consider alternative or expanded operationalisations of identity to provide a more in-depth exploration of how identity processes shape punitive attitudes. Understanding differences in attitudes based on diverse constructions of social identity will better highlight the nature of identity processes in influencing the strength and variance of punitive attitudes toward counter-terrorism measures (see Unnever \& Cullen, 2010a).

\section{Implications of the findings}

Despite the aforementioned limitations, this study extends the current literature by examining predictors of support for punitive counter-terrorism measures in the Australian context. Further, this study explores the interaction between holding a strong national identity and perceiving Muslims as a threat in shaping public support for punitive counter-terrorism policies, a relationship previously untested in the terrorism context. This study evidences associations between strong ingroup identity processes, perceiving Muslims as a threat, and attitudes supportive of punitive counter-terrorism measures. SIT argues that people categorise themselves and others into specific groups, and highlights how intergroup biases can be fostered from perceiving that some groups belong and others do not (Tajfel \& Turner, 1986). Such biases can emerge from perceived threats to an individual's identity, and can lead individuals to protect their identity from such threats (Tajfel \& Turner, 1986; Velasco González et al., 2008). One way to protect one's group can be to support policies perceived to target and control those deemed 'a threat' to the ingroup. A wealth of research shows public support for punitive crime control policies is related to animus towards minority groups (Chiricos et al., 2004; Huddy et al., 2005; Kornhauser, 2013; Unnever \& Cullen, 2010a, 2010b). Findings in the current study show a similar pattern: participants who perceived Muslims to be a greater threat were more likely to supportive of punitive counter-terrorism measures. Relatedly, those who reported having a 
IDENTITY, THREAT AND ATTITUDES TO COUNTER-TERRORISM MEASURES

stronger national identity were also more supportive of punitive measures. These findings support the notion of protecting one's identity when under threat by supporting policies believed to control individuals considered an 'other' (Chiricos et al., 2004).

Results of this study also support the growing literature base (see e.g., Welch, 2016) showing perceptions of threat can impact attitudes towards terrorism policies in much the same way as crime control measures. Stereotypes and prejudice often directed towards minority groups perceived as 'criminals' (Chiricos et al., 2004; Unnever \& Cullen, 2010a, 2012) are observable when examining prejudiced views towards Muslims as 'terrorists'. This is an interesting finding as the focus of the present study was on perceptions of threat towards a group classified by their religion. While other research tends to focus on ethnic or racial animus (Brookman \& Wiener, 2017; Unnever \& Cullen, 2010a), discourses portraying Muslims as a criminal or terrorist other are pervasive (Saeed, 2007; Saleem \& Ramasubramanian, 2017). Thus, demonstrating how negative perceptions of Muslims as a religious group can impact attitudes towards counter-terrorism measures feeds into current social political debates on national security and community safety.

When examining the interaction effect between national identity and perceptions of Muslims as a threat on support for punitive counter-terrorism measures, participants who weakly identified with Australia were most negatively affected by perceiving Muslims as a threat. When Muslims were perceived as a greater threat, low national identifiers became more supportive of punitive counter-terrorism measures. In essence, the perceived threat made them as punitive as strong national identifiers. SIT postulates that the strength of one's identity is fundamental to how they react to identity threats (Stephan et al., 2000), and there is a suggestion that strong ingroup identifiers will be most reactive to threat from outgroup members. The interaction effect 


\section{IDENTITY, THREAT AND ATTITUDES TO COUNTER-TERRORISM MEASURES}

in the current study highlights that low national identifiers are most reactive to greater threat perceptions. While high national identifiers were still more likely to hold punitive attitudes overall regardless of perceiving Muslims as threatening or non-threatening, the fact that low national identifiers were more reactive to threat is somewhat unexpected. This finding suggests that perceptions that Muslims are threatening might be more important for explaining why people support more punitive counter-terrorism measures than holding a strong nationalistic identity. Within the analyses, even when controlling for other variables consistently used in research on punitive attitudes towards crime control, perceptions that Muslims are a threat prevailed as the strongest predictor of support for counter-terrorism measures. Thus, it appears that regardless of the strength of ingroup identification, political preferences, fear of terrorism, or demographic characteristics, perceptions of threat matter most. When considering this notion in the context of terrorism, there are several important implications to note.

Firstly, the public approval of counter-terrorism measures that afford authorities exclusive powers to restrict freedoms points to the potential for the dismissal of fundamental civil liberties, democratic processes, and human rights (Piazza, 2015). This possibility is particularly problematic in the Australian context where no formal Bill of Rights exists (Lynch, et al., 2015). Relatedly, as punitive attitudes can shape policy decisions, it is important to strike a balance between responding to national security threats and enacting appropriate and proportionate measures. This is particularly salient in the Australian context whereby laws are often adapted from the UK, which has experienced more large-scale domestic terrorist events (Williams, 2011). Thus, ensuring that laws are reflective of the threat within Australia is important to the legitimacy and effectiveness of such laws. 


\section{IDENTITY, THREAT AND ATTITUDES TO COUNTER-TERRORISM MEASURES}

Secondly, the influence of perceptions of threat towards Muslims in this study reflects wider "mechanisms of social exclusion" (Chiricos et al., 2004, p. 379). This is ironic as one major focus of counter-terrorism in Australia revolves around strategies to boost social inclusion and cohesion (e.g., the Australian Government's Living Safer Together initiative; Cherney, et al., 2018; Harris-Hogan, Barrelle, \& Zammit, 2016). Moreover, as such approaches require a wholeof-community approach, positive inter-group interactions are crucial. Yet, as Muslims are often the target of counter-terrorism measures, divisive attitudes may flourish and social cohesion may further erode, which can negatively impact the effectiveness of these approaches. Thus, ensuring community strategies are effective in uniting diverse communities is important not only for enhancing social cohesion, but also in shaping wider attitudes towards counter-terrorism responses.

Thirdly, if negative attitudes towards Muslims continue to spread and be tolerated, laws that seek to control those deemed a threat or an other will continue to be used. Unnever and Cullen (2010a) suggest that denouncing public acceptance of policies driven by racial, ethnic, or (in the case of the present study) religious intolerance is contingent on empowering individuals who do not hold prejudiced attitudes to challenge these biases. Empirical evidence indicates that racial profiling is an ineffective counter-terrorism strategy (Harcourt, 2007). Thus, the resilience framework may be useful here. Fostering resilience has become a key feature of counterterrorism, both in preventing and responding to terrorism (Hardy, 2015). In this sense, providing communities with tools and strategies to be resilient in the face of terrorism may also have knock-on effects for how they perceive threats. As such, intolerance of Muslims may be reduced if communities are equipped with the strategies necessary to reduce intergroup biases. 
IDENTITY, THREAT AND ATTITUDES TO COUNTER-TERRORISM MEASURES

Before concluding, it is important to highlight that in the current study Australians in general (regardless of whether they identify strongly or weakly as Australians, or if they perceive Muslims as more or less threatening) were unlikely to support punitive counter-terrorism measures. This can be most clearly demonstrated from Figure 1, where the mean level of support for punitive counter-terrorism measures was quite low (and well under the midpoint of the 5point scale). This finding is reassuring and demonstrates that members of the Australian public disapprove of these measures, despite the increasing severity of sanctions to counter-terrorism. Moreover, in the aftermath of the Christchurch shootings in March 2018 in New Zealand, this finding compliments the tolerant and inclusive atmosphere emanating from the public worldwide and counteracts the more harmful views expressed by others.

\section{Conclusion}

The current study demonstrates a positive association between perceiving Muslims as threatening, holding a strong national identity, and attitudes supportive of punitive counterterrorism measures. Perceptions of threat and support for punitive counter-terrorism measures can exacerbate feelings of exclusion among Muslims (Chiricos et al., 2004), and in some circumstances might fuel some Muslims' support for terrorist ideals and grievances (Cherney \& Murphy, 2017). Thus, results of this research reinforce the need to address wider public attitudes towards Muslims. The next step will be determining how community cohesion and resilience strategies, as key counter-terrorism initiatives, can be shaped around reducing perceptions that Muslims are threatening. This should reduce intergroup biases and enhance a sense of cohesion among ethnic and religious groups living in Australia. 
IDENTITY, THREAT AND ATTITUDES TO COUNTER-TERRORISM MEASURES

\section{References}

Adriaenssen, A., \& Aertsen, I. (2015). Punitive attitudes: Towards an operationalization to measure individual punitivity in a multidimensional way. European Journal of Criminology, 12(1), 92-112.

Akbarzadeh, S. (2016). The Muslim Question in Australia: Islamophobia and Muslim Alienation. Journal of Muslim Minority Affairs, 36(3), 323-333.

Blumer, H. (1958). Race prejudice as a sense of group position. Pacific Sociological Review, $1(1), 3-7$.

Breen-Smyth, M. (2014). Theorising the "suspect community": counterterrorism, security practices and the public imagination. Critical Studies on Terrorism, 7(2), 223-240.

Brookman, R. P., \& Wiener, K. K. (2017). Predicting punitive attitudes: Racial-animus towards new immigrant and Aboriginal minority groups as a mediating agent upon public crime concerns. World Journal of Social Science Research, 4(2), 140-163.

Cherney, A., \& Murphy, K. (2016). Being a 'suspect community'in a post 9/11 world-The impact of the war on terror on Muslim communities in Australia. Australian \& New Zealand Journal of Criminology, 49(4), 480-496.

Cherney, A., \& Murphy, K. (2017). Support for Terrorism: The Role of Beliefs in Jihad and Institutional Responses to Terrorism. Terrorism and Political Violence, 1-21.

Cherney, A., Sweid, R., Grossman, M., Derbas, A., Dunn, K., Jones, C., Hartley, J., \& Barton, G. (2018). Local service provision to counter violent extremism: perspectives, capabilities and challenges arising from an Australian service mapping project. Behavioral Sciences of Terrorism and Political Aggression, 10(3), 187-206. 


\section{IDENTITY, THREAT AND ATTITUDES TO COUNTER-TERRORISM MEASURES}

Chiricos, T., Welch, K., \& Gertz, M. (2004). Racial typification of crime and support for punitive measures. Criminology, 42(2), 358-390.

Doosje, B., Zimmermann, A., Küpper, B., Zick, A., \& Meertens, R. (2009). Terrorist threat and perceived Islamic support for terrorist attacks as predictors of personal and institutional outgroup discrimination and support for anti-immigration policies-Evidence from 9 European countries. Revue Internationale de Psychologie Sociale, 22(3), 203-233.

Frost, N. (2006). The punitive state: Crime, punishment, and imprisonment across the United States. Texas: LFB Scholarly Publishing LLC.

Harcourt, B. E. (2007). Muslim profiles post-9/11: Is racial profiling an effective counterterrorist measure and does it violate the right to be free from discrimination? . In B. Goold \& L. Lazarus (Eds.), Security and Human Rights. Portland, OR: Hart Publishing.

Hardy, K. (2015). Resilience in UK counter-terrorism. Theoretical Criminology, 19(1), 77-94.

Harris-Hogan, S., Barrelle, K., \& Zammit, A. (2016). What is countering violent extremism? Exploring CVE policy and practice in Australia. Behavioral Sciences of Terrorism and Political Aggression, 8(1), 6-24.

Hillyard, P. (1993). Suspect Community: People's Experiences of the Prevention of Terrorism Acts in Britain. London: Pluto Press.

Hopkins, P. E. (2004). Young Muslim men in Scotland: Inclusions and exclusion. Children's Geographies, 2(2), 257-272.

Huddy, L., Feldman, S., Taber, C., \& Lahav, G. (2005). Threat, anxiety, and support of antiterrorism policies. American Journal of Political Science, 49(3), 593-608.

Johnson, D. (2008). Racial prejudice, perceived injustice, and the Black-White gap in punitive attitudes. Journal of Criminal Justice, 36(2), 198-206. Khan, M., \& Ecklund, K. (2012). 


\section{IDENTITY, THREAT AND ATTITUDES TO COUNTER-TERRORISM MEASURES}

Attitudes toward Muslim Americans post-9/11. Journal of Muslim Mental Health, 7(1), 116.

Kornhauser, R. (2013). Reconsidering predictors of punitiveness in Australia: A test of four theories. Australian \& New Zealand Journal of Criminology, 46(2), 221-240.

Li, Q., \& Brewer, M. B. (2004). What does it mean to be an American? Patriotism, nationalism, and American identity after 9/11. Political Psychology, 25(5), 727-739.

Lynch, A., McGarrity, N., \& Williams, G. (2015). Inside Australia's anti-terrorism laws and trials. Sydney: NewSouth Publishing.

Murphy, K. (2013). Policing at the margins: Fostering trust and cooperation among ethnic minority groups. Journal of Policing, Intelligence and Counter Terrorism, 8(2), 184-199.

Murphy, K., Madon, N., \& Cherney, A. (2018). Reporting threats of terrorism: Stigmatisation, procedural justice and policing Muslims in Australia, Policing and Society, 1-17.

Nisbet, E. C., Ostman, R., \& Shanahan, J. (2008). Chapter 9: Public opinion toward Muslim Americans: Civil liberties and the role of religiosity, ideology, and media use. In A. H. Sinno (Ed.), Muslims in Western Politics (pp. 161-199). Bloomington, IN: Indiana University Press.

Oliveira, A., \& Murphy, K. (2014). Race, social identity and perceptions of police bias. Race and Justice, 5(3), 259-277.

Pantazis, C., \& Pemberton, S. (2009). From the 'Old' to the 'New' Suspect Community: Examining the Impacts of Recent UK Counter-Terrorist Legislation. The British Journal of Criminology, 49(5), 646-666.

Piazza, J. A. (2015). Terrorist suspect religious identity and public support for harsh interrogation and detention practices. Political Psychology, 36(6), 667-690. 
IDENTITY, THREAT AND ATTITUDES TO COUNTER-TERRORISM MEASURES

Saeed, A. (2007). Media, racism and Islamophobia: The representation of Islam and Muslims in the media. Sociology Compass, 1(2), 443-462.

Saleem, M., \& Ramasubramanian, S. (2017). Muslim Americans' responses to social identity threats: Effects of media representations and experiences of discrimination. Media Psychology, 1-21.

Sides, J., \& Gross, K. (2013). Stereotypes of Muslims and Support for the War on Terror. The Journal of Politics, 75(3), 583-598.

Stephan, W. G., Diaz-Loving, R., \& Duran, A. (2000). Integrated threat theory and intercultural attitudes: Mexico and the United States. Journal of Cross-Cultural Psychology, 31(2), 240249.

Tajfel, H., \& Turner, J. C. (1986). Chapter 1: The SIT of intergroup behavior. In W. G. Austin \& S. Worchel (Eds.), Psychology of Intergroup Relations (pp. 113-154). Michigan: NelsonHall Publishers.

Unnever, J. D., \& Cullen, F. T. (2010a). Racial - Ethnic Intolerance and Support for Capital Punishment: A Cross - National Comparison. Criminology, 48(3), 831-864.

Unnever, J. D., \& Cullen, F. T. (2010b). The social sources of Americans' punitiveness: A test of three competing models. Criminology, 48(1), 99-129.

Van der Noll, J. (2010). Public support for a ban on headscarves: A cross-national perspective. . International Journal of Conflict and Violence, 4(2), 191-204.

Velasco González, K., Verkuyten, M., Weesie, J., \& Poppe, E. (2008). Prejudice towards Muslims in the Netherlands: Testing integrated threat theory. British Journal of Social Psychology, 47(4), 667-685. 


\section{IDENTITY, THREAT AND ATTITUDES TO COUNTER-TERRORISM MEASURES}

Verkuyten, M., \& Yildiz, A. A. (2010). Religious identity consolidation and mobilization among Turkish Dutch Muslims. European Journal of Social Psychology, 40(3), 436-447.

Weitzer, R., \& Tuch, S. A. (2005). Racially biased policing: Determinants of citizen perceptions. Social Forces, 83(3), 1009-1030.

Welch, K. (2016). Middle Eastern terrorist stereotypes and anti-terror policy support: The effect of perceived minority threat. Race and Justice, 6(2), 117-145.

Williams, G. (2011). A decade of Australian anti-terror laws. Melbourne University Law Review, 35, 1136-1176.

Williamson, Murphy, \& Sargeant, E. (2018). The Attitudes to Punishment Survey Technical Report. Brisbane, Australia: Griffith University.

Zammit, A. (2017). Australian Jihadism in the Age of the Islamic State. CTC Sentinel, 10(3), 2330. 
Table 1

Principal Axis Factor Analysis

\begin{tabular}{lr} 
& \\
\hline Item & .62 \\
\hline 1. Punitive attitudes towards counter-terrorism measures & .71 \\
Authorities should have the powers to question individuals on matters related to terrorism even if \\
they are not suspects & .62 \\
Authorities should be able to detain terrorist suspects without criminal charges for up to 48 hours & .83 \\
Authorities should be able to use stressful interrogation techniques to get confessions from & .77 \\
suspected terrorists & .83 \\
Authorities should be able to listen to private conversations without a court order & .58 \\
Authorities should be able to intercept emails and other personal electronic information & .54 \\
Authorities should be able to conduct searches and seizures of the belongings of suspected & .52 \\
terrorists without proper warrants & \\
Prison sentences for terrorists should be more severe than they currently are & \\
Australian citizenship should be revoked from people with a dual nationality if they are charged & \\
with terrorism offence(s) & Suspected terrorists deserve no legal rights \\
2. National Identity &
\end{tabular}

I am proud to be an Australian

I identify strongly with being Australian

Being an Australian is important to the way I think of myself as a person

\section{Perceptions that Muslims are Threatening}

Australian identity is being threatened because there are too many Muslims

Australian norms and values are being threatened because of the presence of Muslims

Muslims are a threat to Australia's way of life

Muslims are a threat to our safety

I do not trust Muslims

I am suspicious of Muslims 
IDENTITY, THREAT AND ATTITUDES TO COUNTER-TERRORISM MEASURES

Muslims are likely to be potential terrorists .80

Eigenvalues (before rotation)

9.47

49.86

49.86

Eigenvalues (after rotation)

$48.29 \% \quad 10.24 \% \quad 7.92 \%$

Extraction method: Principal Axis Factor analysis with oblimin rotation. Only factor loadings $>0.30$ are presented. 


\section{IDENTITY, THREAT AND ATTITUDES TO COUNTER-TERRORISM MEASURES}

Table 2

Descriptive Statistics and Bivariate Correlations for all Variables and Scales

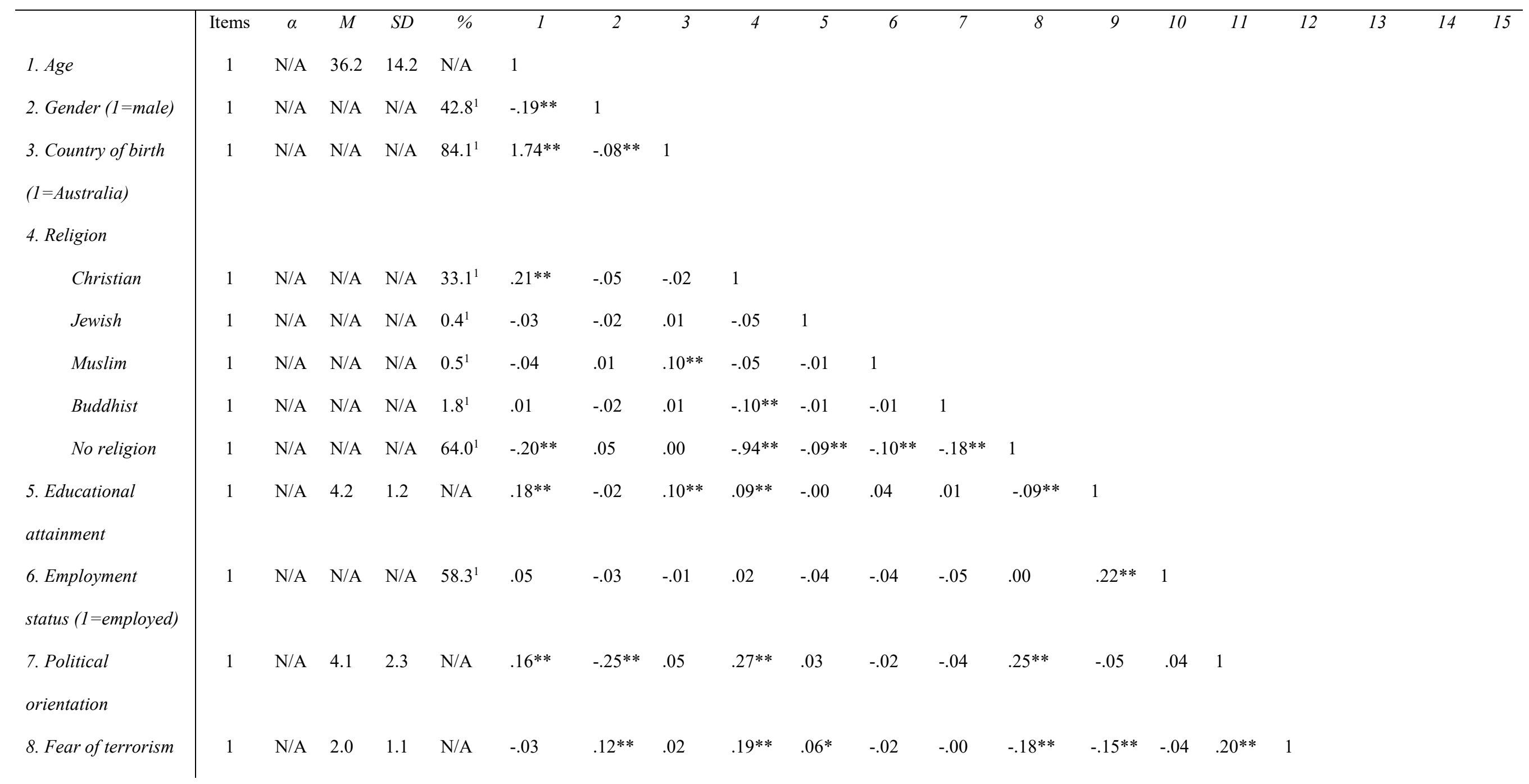


IDENTITY, THREAT AND ATTITUDES TO COUNTER-TERRORISM MEASURES

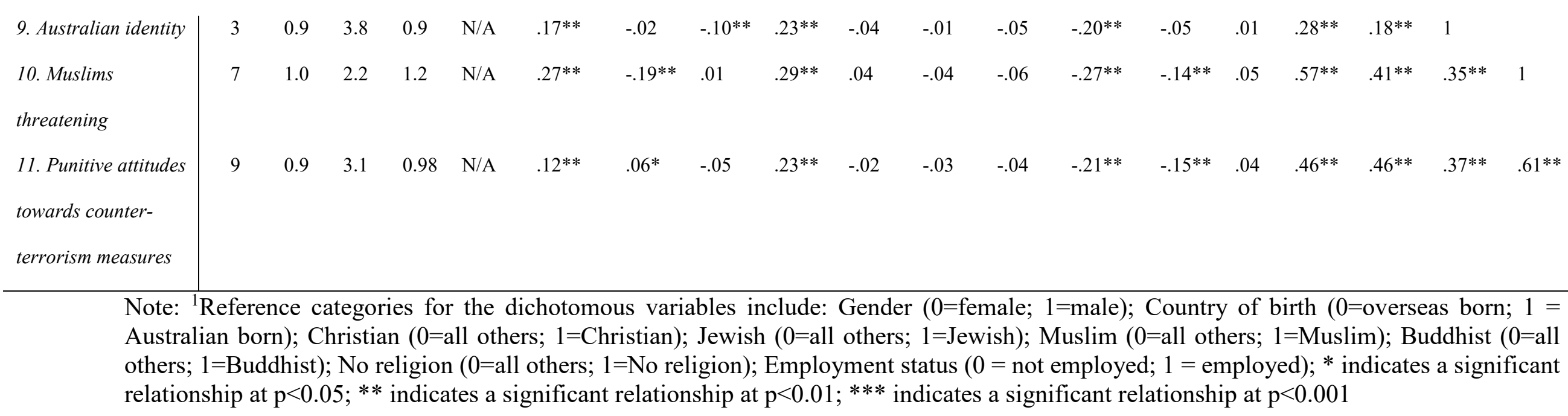

Note: ${ }^{1}$ Reference categories for the dichotomous variables include: Gender $(0=$ female; $1=$ male $)$; Country of birth $(0=$ overseas born; $1=$ Australian born); Christian $(0=$ all others; $1=$ Christian $)$; Jewish $(0=$ all others; $1=$ Jewish $)$; Muslim $(0=$ all others; $1=$ Muslim $)$; Buddhist $(0=$ all others; $1=$ Buddhist $)$; No religion $(0=$ all others; $1=$ No religion $)$ Employment status $(0=$ not employed; $1=$ employed $) ; *$ indicates a significant relationship at $\mathrm{p}<0.05 ; * *$ indicates a significant relationship at $\mathrm{p}<0.01 ; * * *$ indicates a significant relationship at $\mathrm{p}<0.001$ 
IDENTITY, THREAT AND ATTITUDES TO COUNTER-TERRORISM MEASURES

Table 3

OLS Regression Predicting Attitudes Supportive of Punitive Counter-terrorism Measures

\begin{tabular}{|c|c|c|c|c|c|c|}
\hline & \multicolumn{2}{|c|}{ Block 1} & \multicolumn{2}{|c|}{ Block 2} & \multicolumn{2}{|c|}{ Block 3} \\
\hline & $B(\mathrm{SE})$ & $\beta$ & $B(\mathrm{SE})$ & $\beta$ & $B(\mathrm{SE})$ & $\beta$ \\
\hline Constant & $1.363(0.790)$ & & $1.960(0.719)$ & & $1.958(0.715)$ & \\
\hline Age & $0.008(0.002)$ & $0.112 * * *$ & $0.001(0.002)$ & 0.018 & $0.001(0.002)$ & 0.021 \\
\hline Gender $(0=$ male $)$ & $0.250(0.050)$ & $0.125 * * *$ & $0.300(0.045)$ & $0.151 * * *$ & $0.289(0.045)$ & $0.145 * * *$ \\
\hline Country of Birth $(0=$ overseas $)$ & $-0.156(0.065)$ & $-0.058^{*}$ & $-0.071(0.059)$ & -0.026 & $-0.066(0.059)$ & -0.024 \\
\hline Religion & & & & & & \\
\hline Christian & $0.194(0.773)$ & 0.093 & $0.031(0.702)$ & 0.015 & $0.060(0.698)$ & 0.029 \\
\hline Jewish & $-0.541(0.864)$ & -0.033 & $-0.540(0.785)$ & -0.033 & $-0.551(0.781)$ & -0.033 \\
\hline Muslim & $-0.377(0.847)$ & -0.025 & $-0.286(0.769)$ & -0.019 & $-0.261(0.765)$ & -0.018 \\
\hline Buddhist & $-0.036(0.789)$ & -0.005 & $0.009(0.717)$ & 0.001 & $0.055(0.713)$ & 0.008 \\
\hline No religion & $0.093(0.772)$ & 0.045 & $0.029(0.702)$ & 0.014 & $0.065(0.698)$ & 0.031 \\
\hline Educational Attainment & $-0.078(0.020)$ & $-0.097 * * *$ & $-0.034(0.018)$ & -0.042 & $-0.035(0.018)$ & -0.043 \\
\hline Employment Status ( $0=$ not employed) & $0.103(0.042)$ & $0.059 *$ & $0.061(0.038)$ & 0.035 & $0.059(0.038)$ & 0.034 \\
\hline Political Orientation & $0.165(0.011)$ & $0.384 * * *$ & $0.080(0.011)$ & $0.186^{* * *}$ & $0.078(0.011)$ & $0.182 * * *$ \\
\hline
\end{tabular}


IDENTITY, THREAT AND ATTITUDES TO COUNTER-TERRORISM MEASURES

Fear of Terrorism

National Identity

Perception that Muslims are Threatening

Australian ID x Perception of Muslim Threat

$R^{2}$

Adjusted $R^{2}$

$R^{2}$ change

$F$ Change

\begin{tabular}{|c|c|c|c|c|c|}
\hline \multirow[t]{4}{*}{$1.331(0.023)$} & $0.364 * * *$ & $0.206(0.022)$ & $0.227 * * *$ & $0.211(0.022)$ & $0.232 * * *$ \\
\hline & & $0.147(0.024)$ & $0.139 * * *$ & $0.148(0.024)$ & $0.141 * * *$ \\
\hline & & $0.332(0.025)$ & $0.390 * * *$ & $0.340(0.025)$ & $0.400 * * *$ \\
\hline & & & & $-0.069(0.019)$ & $-0.080 * * *$ \\
\hline 0.400 & & \multicolumn{2}{|c|}{0.506} & \multicolumn{2}{|c|}{0.512} \\
\hline 0.393 & & \multicolumn{2}{|c|}{0.500} & \multicolumn{2}{|c|}{0.505} \\
\hline 0.400 & & \multicolumn{2}{|c|}{0.106} & \multicolumn{2}{|c|}{0.006} \\
\hline 61.59 & & \multicolumn{2}{|c|}{118.69} & \multicolumn{2}{|c|}{13.92} \\
\hline
\end{tabular}


Running head: IDENTITY, THREAT AND ATTITUDES TO COUNTER-TERRORISM MEASURES

Figures

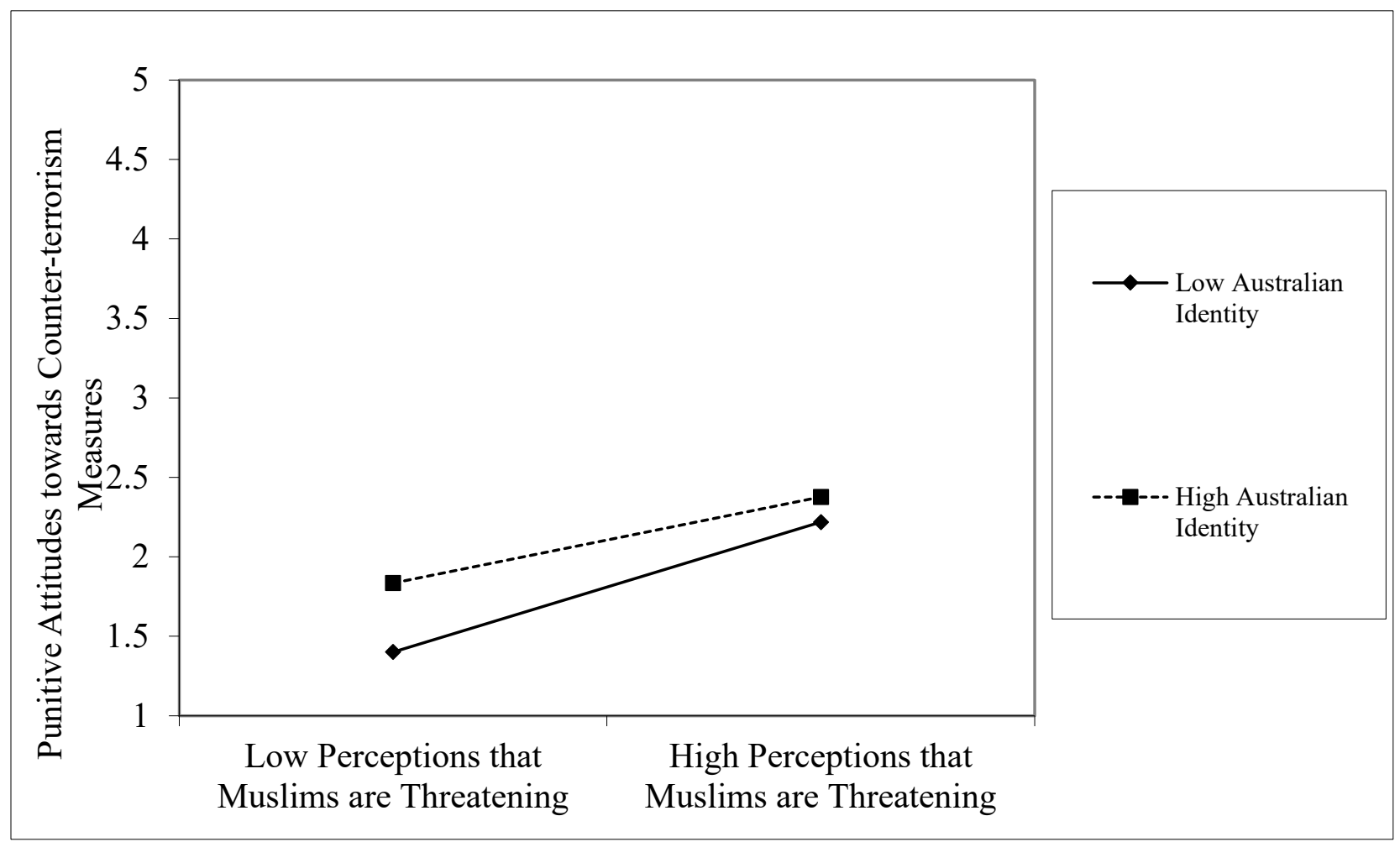

Figure 1. Significant interaction between Australian identity and perceptions that Muslims are threatening on approval of punitive counter-terrorism measures 